\title{
TWO NEW BIRD RECORDS FOR THE TSITSIKAMA NATIONAL PARKS
}

\author{
G. A. ROBINSON \\ Tsitsikama Coastal National Park \\ P. O. Stormsrivier \\ 6308
}

A comprehensive check-list of the birds that possibly could occur in the vicinity of the Parks was published by Skead and Liversidge (1967). They refer to 210 bird species but only record 205; three species were duplicated in Part 1 (forest habitats) and Part 2 (sea habitats). It would appear that two species were omitted from Part 1 . However, one of the species recently recorded should be included in Part 1 while the other belongs to Part 2.

On 1973.07.03 a Lesser Gallinule Porphyrio alleni, (Roberts number 209) was observed outside the boathouse at Storms River Mouth. This bird was captured, fed to a healthy state and eventually released at Nature's Valley.

Prior to the sighting of this bird the weather had been foul with strong south-westerly winds and rough seas and rain. The bird was in a poor state of health - weak and undernourished. As this species selects marshy reeded areas to hive in and no such area exists in the immediate vicinity of Storms River Mouth, it was surmised that the bird had been blown in from one of these habitats west of Storms River. Nature's Valley, nearly $40 \mathrm{~km}$ to the western boundary seemed to be a likely area that would attract Gallinules. Identification was made by comparing the dimensions of the wing, tarsus, culmen, shield width and tail length to those of the Purple, American and Lesser Gallinules as presented by McLachlan and Liversidge (1970). These are listed in Table 1.

More recently on 1975.07.15 another Lesser Gallinule was collected at Storms River Mouth. This bird was found shortly after the same adverse weather conditions had prevailed as the first, i.e. stormy southwesterly winds accompanied by heavy rain. The bird was a juvenile and in a weak and hungry condition, and it was therefore assumed that the bird probably could not have flown. Because the Storms River was in flood during the period of both sightings both birds could have come down the river which is marshy and has reeds upstream.

On the 1973.07.10 a sea-bird in poor condition, which later died, was found on the beach at Nature's Valley. Professor J. M. Winterbottom (pers. comm.), identified the bird as a Blue Petrel Halobaena caerlea (Roberts number 20). Its measurements are given in Table 1.

These two additional records brings the total of birds species for the Parks to 207. 
Table 1

Comparative measurements of gallinules and blue petrels

\begin{tabular}{l|c|c|c|c|c|c|}
\hline & & \multicolumn{2}{|c|}{ GALLINULES } & \multicolumn{2}{c|}{ BLUE PETREL } \\
\hline Measurements & $\begin{array}{c}\text { Storms River } \\
\text { specimen }\end{array}$ & Purple* & $\begin{array}{c}\text { American } \\
\text { Purple* }\end{array}$ & Lesser & $\begin{array}{c}\text { Nature's } \\
\text { Valley } \\
\text { specimen }\end{array}$ & Blue Petrel* \\
Wing & $153 \mathrm{~mm}$ & $225-248 \mathrm{~mm}$ & $162-181 \mathrm{~mm}$ & $144-160 \mathrm{~mm}$ & $217 \mathrm{~mm}$ & $205-221 \mathrm{~mm}$ \\
Tarsus & $44 \mathrm{~mm}$ & $70-92 \mathrm{~mm}$ & $58-62 \mathrm{~mm}$ & $45-56 \mathrm{~mm}$ & $32 \mathrm{~mm}$ & $39-33 \mathrm{~mm}$ \\
Culmen & $37 \mathrm{~mm}$ & $56-71 \mathrm{~mm}$ & $38-48 \mathrm{~mm}$ & $35-40 \mathrm{~mm}$ & $25 \mathrm{~mm}$ & $25-28 \mathrm{~mm}$ \\
Shield width & $11 \mathrm{~mm}$ & $18-24 \mathrm{~mm}$ & - & - & - & - \\
Tail length & $65 \mathrm{~mm}$ & $82-101 \mathrm{~mm}$ & $64 \mathrm{~mm}$ & $66-73 \mathrm{~mm}$ & $104 \mathrm{~mm}$ & $77-91 \mathrm{~mm}$ \\
\hline
\end{tabular}

\section{REFERENCES}

MCLACHLAN, G. R. and R. LIVERSIDGE. 1970. Roberts birds of South Africa. Cape Town: Trustees of the S.A. Bird Book Fund.

SKEAD, C. J. and R. LIVERSIDGE. 1967. Birds of the Tsitsikama Forest and Coastal National Park, 1966. Koedoe 10:43-62. 